Case report

\title{
Rhabdoid Differentiation in Different Types of Renal Cell Carcinoma: A Report of Two Cases and Literature Review
}

\author{
Milena Potić-Floranović ${ }^{1}$, Ana Ristić-Petrović², Filip Veličković3 ${ }^{3}$ Milan Potić4, \\ Tanja Džopalić1, Ljubinka Janković-Veličković \\ ${ }^{1}$ University of Niš, Faculty of Medicine, Scientific Research Center for Biomedicine, Niš, Serbia \\ ${ }^{2}$ Center for Pathology and Pathological Anatomy, Clinical Center Niš, Niš, Serbia \\ ${ }^{3}$ Nuclear Medicine Center, Clinical Center Niš, Niš, Serbia \\ ${ }^{4}$ Urology Clinic, Clinical Center, Niš, Serbia
}

\begin{abstract}
SUMMARY
Rhabdoid morphology is a rare differentiation pattern that can occur in any type of renal cell carcinoma. In approximately $5 \%$ of renal tumors, a variable percent of rhabdoid cells can be seen. Even though these cells resemble rhabdomyoblasts, they are large, with large eccentric nuclei and prominent nucleoli; they have different immunophenotype and ultrastructural features. Tumors with rhabdoid differentiation are classified as grade 4 , they have aggressive clinical behavior and poor prognosis. We present two cases of 83-year-old and 60-year-old male patients. Samples of both patients were obtained after radical nephrectomy. In the first patient, papillary renal cell carcinoma was verified, and its phenotype was immunohistochemically demonstrated. Cells with papillary morphology were mixed with rhabdoid cells arranged in sheet-like, pseudotubular and organoid structures. The second patient had the incidentally discovered clear cell renal cell carcinoma with rhabdoid differentiation, together with adenocarcinoma of the colon. Histopathological evaluation showed cells that were typical for clear cell carcinoma and large non-cohesive rhabdoid cells as well. Giant, bizarre multinuclear cells were also noted. Homogenous rhabdoid morphology accounted for about $60 \%$ of the tumor.

Rhabdoid differentiation in renal cell carcinoma is a high-grade morphological feature. It is associated with poor outcome, and distant metastases are commonly present at the time of diagnosis. In order to clarify the significance of this type of divergent differentiation on prognosis, future treatment options and outcome of the disease, further analysis of a larger number of cases is necessary.
\end{abstract}

Key words: renal cell carcinoma, rhabdoid differentiation, prognosis

Corresponding author:

Milena Potić-Floranović

Email: milenapotic@yahoo.com 


\section{INTRODUCTION}

Renal cell carcinoma (RCC) represents the most common renal tumor, and accounts for about $21 \%$ of urinary tumors, following the prostate and bladder cancers (1). Rhabdoid morphology is a rare differentiation pattern, and refers to the presence of tumor cells that resemble rhabdomyoblasts. However, they have different immunophenotype and ultrastructural features. Rhabdoid differentiation is present in approximately $5 \%$ of tumors, and can occur in any RCC type: clear cell (ccRCC), papillary, chromophobe, renal medullary carcinoma, renal ductal carcinoma of Bellini and malignant mixed epithelial and stromal tumor of the kidney. The International Society of Urological Pathology (ISUP) 2012 Consensus Conference classified tumors with rhabdoid differentiation as grade 4 , with an aggressive clinical behavior and poor prognosis $(1,2)$.

We present two cases of 83-year-old and 60year-old male patients, the first of whom presented with hematuria and abdominal pain, whereas the second case was incidentally detected after the discovery of adenocarcinoma of the colon. The first patient had the case of rhabdoid differentiation in papillary RCC and the second patient had clear cell RCC with rhabdoid differentiation.

\section{CASE 1}

An 83-year-old man was admitted due to abdominal pain and microscopic haematuria. Imaging

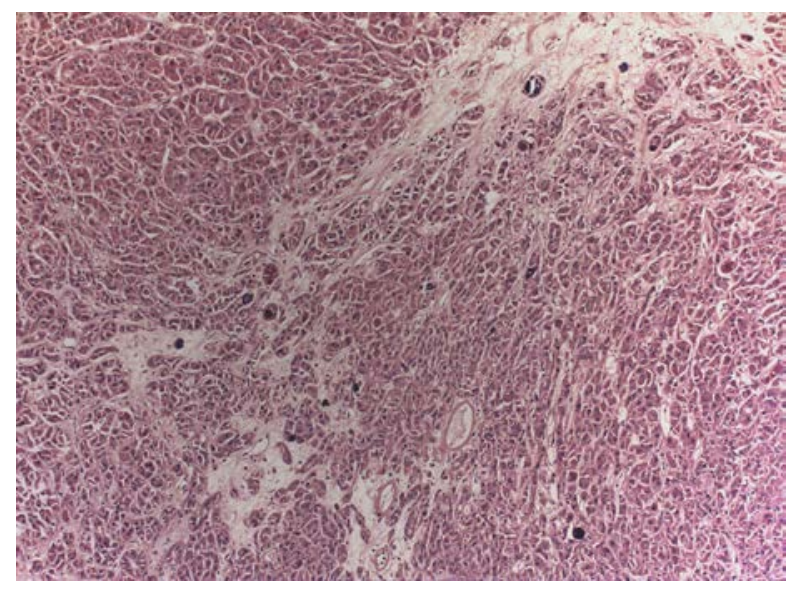

Figure 1. Papillary RCC with psammoma bodies (HEx100) revealed a renal mass of $8.5 \times 6.3 \mathrm{~cm}$ in size, located predominantly in the renal pelvis, that was radially spreading toward the renal cortex, with scattered foci of calcifications. Bone scan ruled out distant metastases. Radical nephrectomy was performed. A gross tumor measured $8 \times 6 \mathrm{~cm}$ in size. It was well circumscribed, red-brown, friable, and did not penetrate a renal capsule. The tissue was then fixed in $4 \%$ neutral formaldehyde, embedded in paraffin, cut in $4-\mu \mathrm{m}$-thin sections, and stained with hema-eosin. An immunohistochemical study was performed, and the primary antibodies used were: RCC, CD10, CD117, vimentin, CKAE1/AE3, CK7, epithelial membrane antigen (EMA) and Ki-67.

Histopathological evaluation showed classical papillary RCC morphology: eosinophilic cells with prominent nuclei forming tubulopapillary structures, containing foamy macrophages, psammoma bodies and hemosiderin (Figure 1). Rhabdoid cells, with eosinophilic and granular cytoplasm, large eccentric nuclei and prominent nucleoli, were present among them (Figure 2). They were arranged in sheet-like, pseudotubular and organoid structures separated by thin septae. Fields of necrosis were also noted. Renal vein invasion was not detected. Immunohistochemical study expressed strong positivity to RCC, CD10 (Figure 3), CD117 (Figure 4.), vimentin, CKAE1/AE3 and weak EMA positivity. The cells were negative to $\mathrm{CK} 7$, and to myogenic markers, desmin and myoglobin. Ki proliferative index was $11 \%$. Tumour was given grade 4 according to ISUP standard of classification.

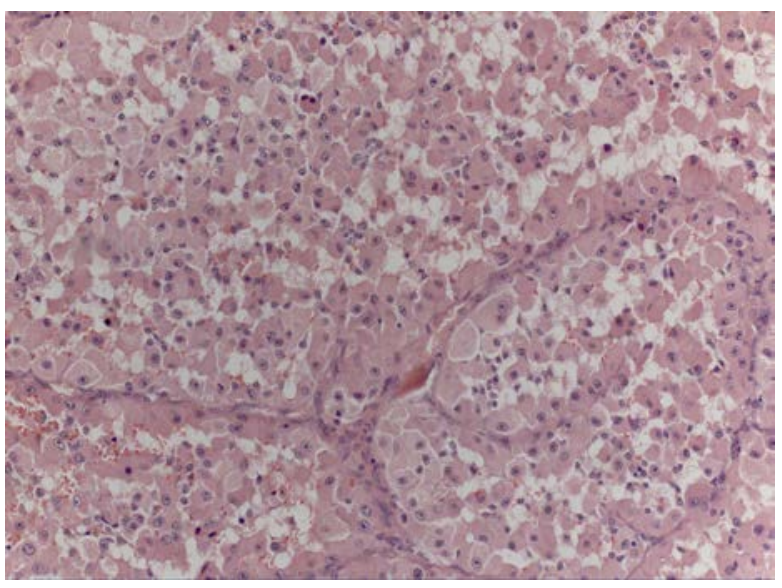

Figure 2. Neoplastic cells with rhabdoid morphology (HEx200) 


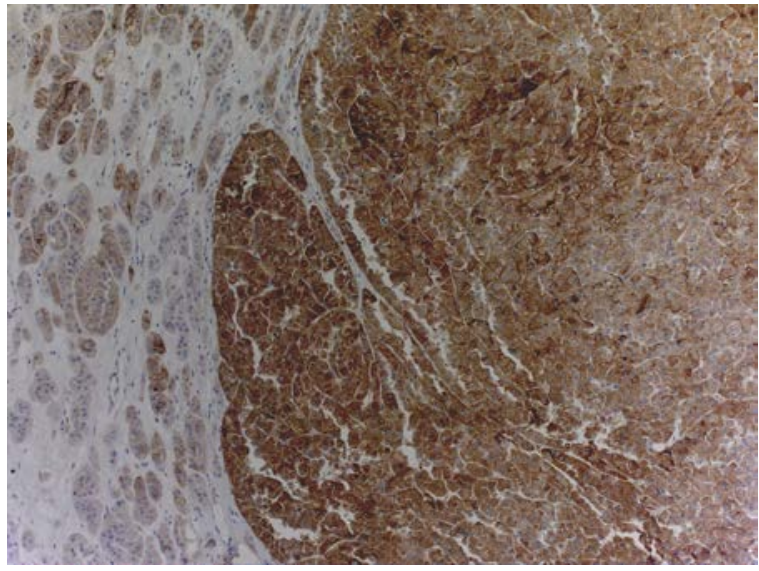

Figure 3. Tumour cells express immunopositivity (x100) for CD10 (x100)

\section{CASE 2}

The 60-year-old male patient was admitted due to the complaints associated with digestive system: obstipation and bloody stool. Endoscopic examination showed ulcero-vegetative mass in the transversal colon. Computed tomography scan (CT) showed a mass measuring $4 \mathrm{~cm}$ within the lumen of transversal colon. It also showed possible deposits in four lymph nodes, as well as a single liver lesion. On the upper pole of the right kidney, a mass, measuring $5 \mathrm{~cm}$ was detected. Surgical procedure was performed and part of the transversal colon and the right kidney were extracted.

Grossly, a removed bowel segment measured $50 \mathrm{~cm}$, and $10 \mathrm{~cm}$ away from the resection border there was an ulcero-vegetative mass completely obstructing the lumen, penetrating through the intestinal wall into the adipose tissue. The kidney showed a grayish-yellow friable lesion, measuring $5 \times 4 \mathrm{~cm}$. It was clearly demarcated from the surrounding parenchyma. The invasion of the renal capsule was not present. Surgically renal vein cut margins were free of tumor.

Tissue samples were fixed, embedded in paraffin, cut and stained with hematoxylin-eosin.

Histologically, in the transversal colon, adeno-

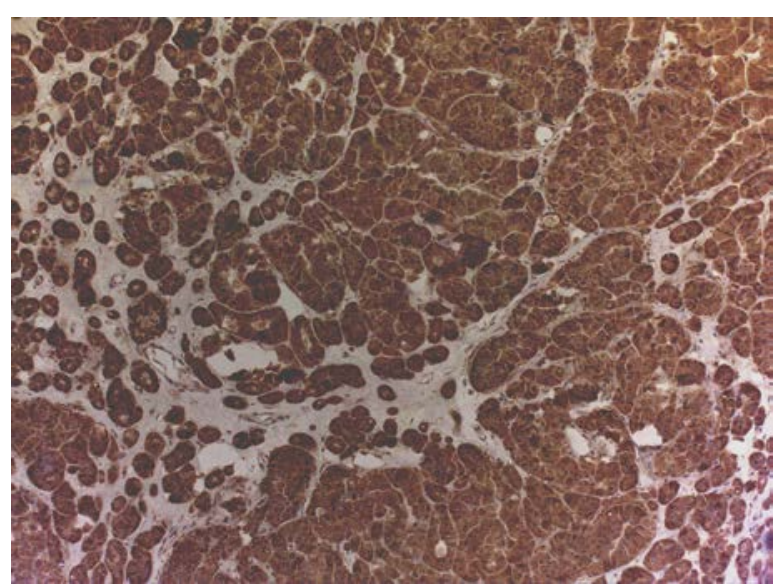

Figure 4. Strong CD117 immunopositivity

carcinoma with partial mucinous features was detected. The tumor showed massive necrosis, vascular invasion, as well as the invasion of the pericolic adipose tissue. Four out of 19 extracted lymph nodes were positive for cancer.

Histopathological examination of the kidney tumor showed classical clear cell RCC, Fuhrman grade 2 with optically clear cells with large centrally placed nuclei (Figure 5). However, large noncohesive rhabdoid cells were present as well. Those cells were oval to polygonal, arranged as tubular and diffuse sheets, with abundant eosinophilic cytoplasm and paranuclear intracytoplasmic inclusions, surrounded with inflammatory infiltrate. They had large vesicular eccentric nuclei with prominent nucleoli. Giant, bizarre multinuclear cells were also noted (Figure 6). Some fields showed rhabdoid cells mixed with conventional clear cells, but homogenous rhabdoid morphology accounted for about $60 \%$ of the tumor. Fields of hemorrhage and necroses were observed, and the tumor was given Fuhrman grade 4 . There was no vascular invasion, nor the invasion of the renal capsule. Immunohistochemical study expressed strong positivity for RCC (Figure 7), vimentin and CD10 (Figure 8), and negativity for CD117, CK7, and CK20. 


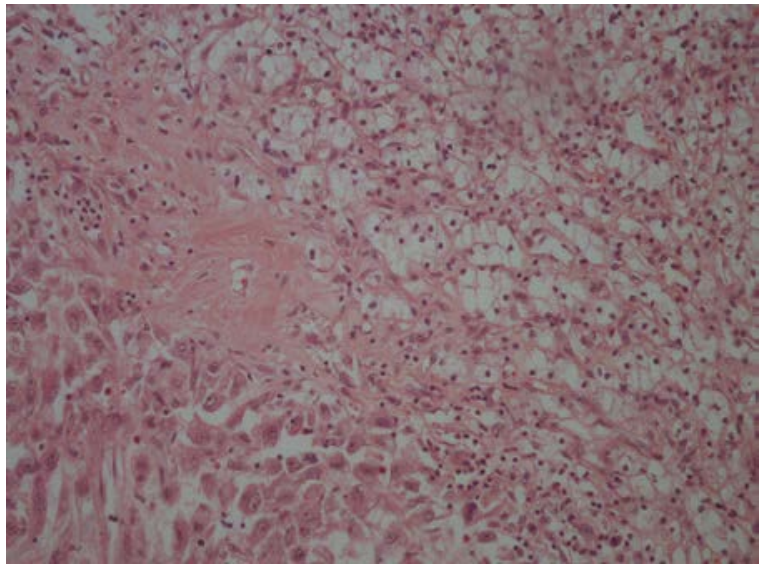

Figure 5. Neoplastic cells with rhabdoid (left) and clear cell morphology (right) (Hex100)

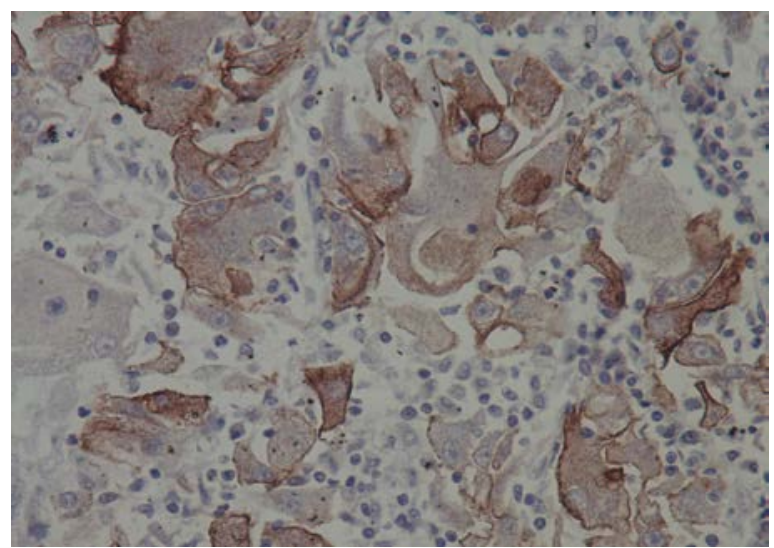

Figure 7. Rhabdoid cells express RCC positivity

\section{DISCUSSION}

Rhabdoid differentiation indicates that RCC tumors contain various amounts (5\%-90\%) of neoplastic cells that morphologically resemble rhabdomyoblasts. However, they do not have the ultrastructure of rhabdomyoblsts, and their immunohistochemical staining is different. This is a rare entity, and its incidence is not clearly known, ranging from $1,4 \%$ to $7 \%$ in various reported series (1-5). Mean age of the patients with rhabdoid RCC is between 52 to 63 years and male to female ratio is $2: 1(5,6)$. Rhabdoid differentiation can occur in any histologic subtype of $\mathrm{RCC}$, but it is most commonly found in ccRCC. If the tumor contains only rhabdoid-like cells without fields of well differentiated tumor, it should be diagnosed as: "unclassified carcinoma with a rhabdoid compo-

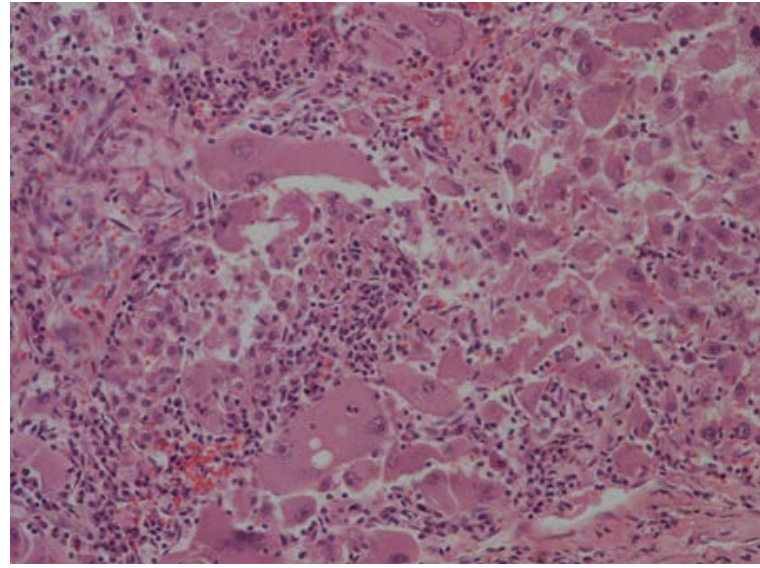

Figure 6. Large multinuclear cells with rhabdoid morphology (HEx200)

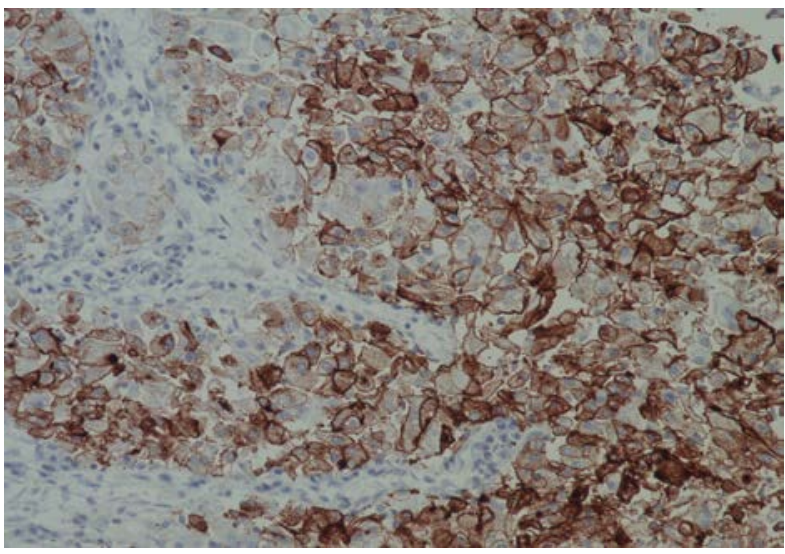

Figure 8. Rhabdoid cells express strong CD10 positivity

nent" $^{\prime \prime}(1,5,6)$. In our first case, rhabdoid phenotype was present in about $50 \%$ of tumor mass, and in our second case, it was present in about $60 \%$ of tumor mass.

Rhabdoid morphology microscopically refers to large, oval to polygonal cells with abundant cytoplasm that contains globular eosinophilic inclusions. They have large, vesicular eccentric nuclei with prominent nucleoli. The cells can sometimes be bizarre and multinuclear, discohesive and scattered, or they can form various growth patterns including solid, organoid or sheet-like $(4,5,7)$. Transition zones between traditional RCC morphology and rhabdoid component can often be seen $(4,7)$. Tumor necrosis is common and can be extensive as well as hemorrhage. Although rhabdoid cells microscopically resemble 
rhabdomyoblasts, they differ in ultrastructural features and immunophenotype. Ultrastructurally, rhabdoid cells have paranuclear aggregates, which represent tangled intermediate filaments, opposed to rhabdomyoblasts which contain sarcomeres (thick and thin filaments) and $\mathrm{Z}$ bands $(5,6,8)$.

Immunohistochemically, the rhabdoid cells are usually positive for vimentin, epithelial membrane antigen (EMA), Pan-cytokeratin (AE1/AE3), CK8/18, Renal Cell Carcinoma Marker (RCC), CD10, PAX8 and often p53. They stain negatively for conventional myogenic markers including desmin, myoglobin, myogenin and Myo D1. They are also negative for smooth muscle actin, GFAP, CK7 and CK20. Rhabdoid differentiated tumors generally have higher proliferative index (Ki-67) compared to conventional tumors, and p53 reactivity is often higher in rhabdoid areas compared to clear cell areas. This indicates a higher proliferative activity and could also represent progression to aggressive biological behavior $(4,5,7$, 9, 10). Our first case showed positivity for RCC, CD10, vimentin, CD117, CKAE1-AE3, and wage focal EMA positivity. The proliferative index was $11 \%$. Numerous studies demonstrated CD117 negativity on these cells $(4,7)$, however, our first case of papillary RCC with rhabdoid differentiation showed strong CD117 positivity. Our second case showed positivity for vimentin, CD10 and RCC.

Pediatric rabdoid tumor is rare but a wellknown tumor of infancy. It has morphological similarity to adult RCC with rhabdoid differentiation, but is regarded as a separate entity due to the loss of INI1 nuclear staining, caused by the mutation of hSNF5/INI1/SMARCB1 gene at 22q11.2. In adult RCC with rhabdoid differentiation, INI1expresion and therefore INI-1 immunopositivity are retained, except in cases of renal medullary carcinoma $(11,12)$.

A widely accepted theory today is that rhabdoid phenotype arises due to the dedifferentiation of neoplastic cells that could be originally classified as one of the conventional RCC subtypes. Facts supporting this theory are that rhabdoid and conventional tumoral foci have similar immunophenotype, as well as the presence of transitional zones between rhabdoid tumor and classical RCC, and ultrastructural difference from myogenic cells $(5$, $7,9)$. Certain studies suggest that the rhabdoid and non-rhabdoid RCC components have the same clonal origin, which is most likely to be renal tubular epithelial cell $(4,9)$. In both of our cases transitional zones were not clearly marked. In the second case, rhabdoid elements were entangled with tumor cells with clear cell morphology and with variable grade as well.

The study of genetic alterations in RCC with rhabdoid differentiation showed that these tumors share genetic alterations with coexisting RCC. They, however, exhibited a larger number of altered genes (gained or lost), and more copy number variations for certain chromosomes. In rhabdoid areas, there is a higher frequency of loss of chromosomes 9, 11q, 17p compared to RCC areas (13).

According to the ISUP grading system, the presence of rhabdoid differentiation is a high-grade morphological feature and should be classified as Fuhrman grade 4 (1). It is associated with poor outcome, with 15\%-22\% 5-year survival reported, and distant metastases commonly present at diagnosis (1, 5). Previous researches have demonstrated that RCC with a rhabdoid component has an aggressive clinical behavior and poor prognosis. Przybycin et al. demonstrated on 49 patients that rhabdoid differentiation in RCC increased the risk of death independently of other prognostic factors (2). Metastasis can occur in up to $70 \%$ of the cases, and distant metastases can affect lung, adrenal gland, bone, soft tissue, liver, lymph nodes or skin $(2,5,6,10,14)$. Cancer-specific mortality rate is $40 \%-50 \%$ (10).

Recent survival analyses study have shown that RCC patients, without lymph node involvement or distant metastasis (NOM0) but with rhabdoid differentiation, have been associated with poor recurrence free survival (15). Those results also showed that these patients had shorter recurrence time, consequently resulting in poor prognosis, thus suggesting that patients with rhabdoid differentiation should be closely observed and considered for postoperative adjuvant therapy.

The ISUP drew attention that in RCC rhabdoid foci could occasionally be seen together with sarcomatoid differentiation and are both classified as WHO/ISUP grade 4 (1). However, Zhang et al. suggest that rhabdoid and sarcomatoid differentiation should not be grouped together when assessing the risk in patients with grade 4 RCC, because only sarcomatoid differentiation was shown to be a statistically significant prognostic feature. Their results still support the ISUP grading system that classifies any tumor with rhabdoid differentiation as grade 4 (14).

Radical nephrectomy is recommended as a standard treatment of RCC. Some cases with rhabdoid 
differentiation responded to tyrosine kinase inhibitors (sorafenib and sunitinib) (5). Due to a limited number of cases, there is no standardized treatment and further studies are needed in order to predict the effectiveness of therapeutic agents in RCC with rhabdoid differentiation.

\section{CONCLUSION}

Rhabdoid components in RCC are associated with aggressive clinical behavior and poor prognosis. These cells represent divergent differentiation of a classifiable-type RCC, with shared genetic background. Their presence should be described in pathology reports. Further accumulation of cases will be necessary in order to clarify the significance of rhabdoid morphology in prognosis, future treatment options and outcome for these patients.

\section{Acknowledgement}

This work was supported by grant No. 175092 from the Ministry of Education and Science of the Republic of Serbia.

\section{Conflicts of Interest}

Authors declared no conflict of interest. 


\section{References}

1. Warren AY, Harrison D. WHO/ISUP classification, grading and pathological staging of renal cell carcinoma: standards and controversies. World J Urol 2018; 36(12):1913-26. https://doi.org/10.1007/s00345-018-2447-8

2. Przybycin CG, McKenney JK, Reynolds JP, et al. Rhabdoid diferentiation is associated with aggressive behavior in renal cell carcinoma: a clinicopathological analysis of 76 cases with clinical follow-up. Am J Surg pathol 2014; 38(9):1260-5.

3. Shannon B, Stan Wisniewski Z, Bentel J, et al. Adult rhabdoid renal cell carcinoma. Arch Pathol Lab Med 2002; 126:1506-10.

4. Yang $\mathrm{X}, \mathrm{Xi} \mathrm{C}$, Jin J, et al. Adult renal cell carcinoma with rhabdoid differentiation: incidence and clinicopathologic features in Chinese patients. Ann Diagn Pathol 2015; 19(2):57-63.

https://doi.org/10.1016/j.anndiagpath.2015.01.006

5. Kuroda N, Karashima T, Inoue K, et al. Review of renal cell carcinoma with rhabdoid features with focus on clinical and pathobiological aspects. Pol J Pathol 2015; 1:3-8.

https://doi.org/10.5114/pjp.2015.51147

6. Delahunt B, Cheville JC, Martignoni G, et al. The international society of urological pathology (ISUP) grading system for renal cell carcinoma and other prognostic parameters. Am J Surg Pathol 2013; 37:1490-504.

7. Chapman-Fredricks JR, Herrera L, Bracho J, et al. Adult renal cell carcinoma with rhabdoid morphology represents a neoplastic dedifferentiation analogous to sarcomatoid carcinoma. Ann Diagn Pathol 2011;15: 333-7. https://doi.org/10.1016/j.anndiagpath.2011.03.002

8. Humphrey PA. Renal cell carcinoma with rhabdoid features. J Urol 2011; 186: 675-6. https://doi.org/10.1016/j.juro.2011.05.016

9. Leroy X, Zini L, Buob D, et al. Renal cell carcinoma with rhabdoid features. An aggressive neoplasm with overexpression of p53. Arch Pathol Lab Med 2007; 131:102-6.

10. Esnakula AK, Naab TJ, Green W, et al. Extensive peritoneal carcinomatosis secondary to renal cell carcinoma with sarcomatoid and rhabdoid differentiation. BMJ Case Rep 2013; 22:2013

11. Divya AA, Siddhi GS, Avinash RJ, et al. Renal cell carcinoma with rhabdoid differentiation: A novel entity with immunohistochemical study. Indian J Pathol Microbiol 2016; 59:656-7. https://doi.org/10.4103/0377-4929.191778

12. Cheng JX, Tretiakova M, Gong C, et al .Renal medullary carcinoma: rhabdoid features and the absence of INI1 expression as markers of aggressive behavior. Mod Pathol 2008; 21(6):64752.

https://doi.org/10.1038/modpathol.2008.44

13. Perrino $\mathrm{CM}$, Hucthagowder $\mathrm{V}$, Evenson $\mathrm{M}$, Kulkarni S,e al. Genetic alterations in renal cell carcinoma with rhabdoid differentiation. Human Pathol 2015; 46(1):9-16. https://doi.org/10.1016/j.humpath.2014.09.001

14. Zhang BY, Cheville JC, Thompson RH, et al. Impact of Rhabdoid Differentiation on Prognosis for Patients with Grade 4 Renal Cell Carcinoma. Eur Urol 2015; 68(1):5-7. https://doi.org/10.1016/j.eururo.2015.01.002

15. Kim $H$, Inomoto $C$, Uchida $T$, et al. Impact of rhabdoid differentiation on postoperative outcome for patients with NOM0 renal cell carcinoma. Urologic Oncology: Seminars and Original Investigations 2019; 37(10):711-20. https://doi.org/10.1016/j.urolonc.2019.05.012 


\title{
Rabdoidna diferencijacija u različitim tipovima karcinoma bubrežnih ćelija: prikaz dva slučaja i pregled literature
}

\author{
Milena Potić-Floranović ${ }^{1}$, Ana Ristić-Petrović ${ }^{2}$ Filip Veličković3, Milan Potić4, \\ Tanja Džopalić1, Ljubinka Janković-Veličković ${ }^{2}$ \\ ${ }^{1}$ Univerzitet u Nišu, Medicinski fakultet, Naučno istraživački centar za biomedicinu, Niš, Srbija \\ ${ }^{2}$ Centar za patologiju i patološku anatomiju, Klinički centar Niš, Nišs, Srbija \\ ${ }^{3}$ Centar za nuklearnu medicine, Klinički centar Niš, Niš, Srbija \\ ${ }^{4}$ Klinika za urologiju, Klinički centar Nišu, Niš, Srbija
}

\section{SAŽETAK}

Rabdoidna morfologija je redak oblik diferencijacije, koji se može registrovati u bilo kom tipu karcinoma bubrežnog parenhima. U približno $5 \%$ renalnih tumora mogu se sresti rabdoidne ćelije zastupljene u različitim procentima. Iako ove ćelije morfološki nalikuju rabdomioblastima, one krupne su sa eozinofilnom citoplazmom, krupnim ekscentričnim nukleusom i prominentnim nukleolusom, te poseduju drugačiji imunofenotip i drugačije ultrastrukturne karakteristike. Tumori sa rabdoidnom diferencijacijom klasifikuju se kao gradus 4, imaju agresivan tok i lošu prognozu. Predstavljamo dva slučaja karcinoma bubrežnih ćelija sa rabdoidnom diferencijacijom kod bolesnika starosti 83 godine i 60 godina. U oba slučaja, uzorci su dobijeni nakon radikalne nefreketomije a zatim histološki obrađeni. Kod prvog bolesnika verifikovano je prisustvo papilarnog karcinoma bubrega, čiji je fenotip imunohistohemijski dokazan, a takođe su uočene rabdoidne ćelije organizovane $\mathbf{u}$ traksate, pseudotubularne $\mathbf{i}$ organoidne strukture. Kod drugog bolesnika svetloćelijski karcinom bubrega otkriven je incidentalno, zajedno sa adenokarcinomom kolona. Tumor bubrega je uz klasičnu svetloćelijsku morfologiju, pokazivao i prisustvo krupnih, nekohezivnih rabdoidnih ćelija, kao i džinovske, bizarne, multinuklearne ćelije. Homogena rabdoidna morfologija sačinjavala je oko $60 \%$ tumora.

Rabdoidna diferencijacija u karcinomu bubrega karakteristika je slabo diferentovanog tumora visokog gradusa. Povezana je sa lošim ishodom i čestim udaljenim metastazama prisutnim u vreme dijagnostike. Za utvrđivanje uticaja ovog oblika divergentne diferencijacije na prognozu, izbor terapijskog modaliteta $i$ ishod bolesti potrebna je analiza većeg broja slučajeva.

Ključne reči: karcinom bubrežnog parenhima, rabdoidna diferencijacija, prognoza 